\title{
Effect of Non-farm income on Poverty Status Among rural farmers in Pakistan (A Case Study of Tehsail Bahrain District Swat)
}

\author{
Waqar Ahmad and Tingwu Yan \\ College of Economics and Management, Huazhong Agricultural University, Wuhan, 430070, Hubei P.R.China.
}

Correspondence Author: Waqar Ahmad, College of Economics and Management, Huazhong Agricultural University, Wuhan, 430070, Hubei P.R.China.

Received date: 22 December 2017, Accepted date: 22 January 2018, Online date: 5 February 2018

Copyright: (C) 2018 Waqar Ahmad. This is an open-access article distributed under the terms of the Creative Commons Attribution License, which permits unrestricted use, distribution, and reproduction in any medium, provided the original author and source are credited.



Key words: Rural farmers, Poverty, Non-farm income, Farm income, Pakistan.

\section{INTRODUCTION}

Pakistan is a developing country which have a problem of poverty, Every third pakistani is caught in the poor bracket and the incidence of poverty has increased $26.6 \%$ in 1993to $32.2 \%$ in 1999 and the number of poor have risen by over 12 million people during this period.So its very likely that the incidence of poverty in pakistan today is much higher than in 1999.Poverty in Pakistan has historically higher in the urban areas and inequalty also increased in pakistan during the 1990, in urban and rural areas [1].In Pakistan Poverty is Increasing day by day due to political instability, law and order situation, and unequal distribution of income, So Govt should make BISP Program more fair, and improve its quantity to Reduce poverty from Rural areas. [2].

Poverty reduction has become a major political concern in pakistan since its independent and especially in the last seven years.according to the estimate of study ,55\% of families are poor and this level of rural poverty is significantly higher than the other rural areas of the punjab province.The government should pay particular attention by lowering the size of the family,education improvement,and other socio-economic aspects to alleviate rural poverty in pakistan [3]. In Pakistan nearly 38 percent of population lived below the poverty line during the year 2015-16.the incidence, depth and severity of rural poverty are relatively larger than urban areas. They also reveals that the incidence of national poverty in terms of percentage of the population is similar to that estimated for the year 2010-11.however, with regard to the absolute number of poor, 74 million estimated in the year 2015-16, while the population it was 61 million in the year 201011.risk of being vulnerable to poverty in rural areas was relatively higher than the impact of the vulnerability on the urban counterpart [4].It is true that in Pakistan redistribution often has limited potential and that the growth of this is necessary condition for poverty reduction. The level of inequality influences the degree of poverty and the elasticity of the growth of poverty.in addition, a low level of inequality contributes to an acceleration of poverty reduction for a certain level of growth. The search for effective policies to reduce poverty, or at least prevent them from rising, should be an integral part of the development agenda [5].

Participation in Non-agricultural activities for both men and women has a positive impact on domestic welfare in Pakistan by increasing income levels and reduce poverty. However, the impact is higher if the males of a household take part in these activities rather than females and higher levels of education lead to a greater impact on household incomes and poverty reduction [6].Non-agricultural income plays an increasingly important role in sustainable development and poverty reduction in rural areas [7].The farmers who participating in Non-farm activities they improve their income very fast and reduce poverty quickly while those who cannot participating in non-farm activities they cannot reduce poverty so fast [8].

Throughout the world, rural households participate in a variety of non-farm activities to generate income [9].Income from Agriculture, risk tools is high while in non-agricultural risk tools is low and household can easily increased his income in a short time period and also can help to maintain stable level of food security[10].Rural non-farm income not only increase household income but also reduce poverty from rural household [11].Non-agricultural income is an important source of income for farmers, $78.5 \%$ of farmers receive income from non-agricultural sectors. Non-farm income not only reduce poverty, but also decrease inequality [12].Non-farm income plays a very important role in household income. Non-farm income reduce inequality from rural household. Mostly Poor people of the rural areas are involved in Non-farm activities and they get more benefit from this sector [13].Non-farm income reduce poverty from rural household by $57 \%$ in Pakistan. But the researcher said that we should also promote agriculture because without agricultural sectors economy cannot do high development [14]. In view of this research field we analyses the effect of non-agricultural income on poverty status among farmers in Tehsail Bahrain District Swat Pakistan. To Specifiy the Socio-economic Characteristic of farmers,study of proportions income from non-agricultural income and identification of factors influencing poverty levels among the farmers.

Research Objective and Hypotheses:

Objective of the study are:The purpose of this study was to mention the main factors affecting the performance of non-farm income and also Identify the ways in which rural non-farm income contribute to poverty alleviation.

The Significance of the study: 
Citation: Waqar Ahmad and Tingwu Yan, 2018. Effect of Non-farm income on Poverty Status Among rural farmers in Pakistan (A Case Study of Tehsail Bahrain District Swat). Advances in Environmental Biology., 12(1): 6-10

This research will provide useful information about the non-farm income, and reduction of poverty from rural farmers in Kpk, Pakistan. The results of this study will also helpful for Khyber-Pakhtunkhwa government, and for those who making policy.

\section{Research Hypothesis}

There is a relationship between the social and economic characteristic of the participating household and performance of non-agricultural activities. Non-agricultural activities contribute to poverty reduction in participating households.

Methodology and Data

Description of the study area; This research was conducted in Tehsail Bahrain District Swat, Kpk Province of Pakistan in May, 2017 to august 2017 .In this area poverty is so high because most of the people depend on agriculture and 2010, flood destroyed most of the infrastructure, cultivated land, health facilities etc., for this reason the author select this area for research. Tehsail Bahrain is a hill station, total population of tehsail Bahrain was 248,474(Pakistan Bureau of statistic (web)),located $60 \mathrm{~km}$ North of Mingora at an Altitude of 4700ft on the right bank of Swat River. The Average temperature in Tehsail Bahrain is 16.6 Celsius (61.88 Fahrenheit), November is the Driest month while March, is the wettest month, July is hottest month of the year with an average temperature of 27.0 Celsius, while January is the coldest month of an average temperature 4.8 [15].

Table 1.1: land Uses of Swat Valley

\begin{tabular}{|l|l|l|}
\hline S.No & Land Uses & Percentage \\
\hline 1 & Forests & $22.84 \%$ \\
\hline 2 & Agriculture & $39.46 \%$ \\
\hline 3 & Waste land others & $37.70 \%$ \\
\hline 4 & Totals & $100 \%$ \\
\hline
\end{tabular}

Source :( Khyber Pakhtunkhwa, FD 2010)

Data Collection:

Tehsail Bahrain economies are based on agriculture. The production of food crops provides income to the population. The agriculture is rain -fed in Tehsail Bahrain Swat Pakistan and the people are predominantly farmers. Primary data were collected through a structured questionnaire. A multistage sampling technique was used in selecting the respondents used for this study. The random selection of 300 farmers from Tehsail Bahrain District swat was selected. Simple language was used for the designing of questionnaire so that everyone can easily understand and is tried to avoid technical terms because majority of the population belong to low income groups, having low level of education. Descriptive statistics, relative poverty measure and Tobit-Regression Analysis was used to analyses the data collected. The relative poverty measure is used to categories the respondents based on a measure of per capita expenditure of households on food and non-food items while Tobit- regression analysis was used to analyses the factors influencing the poverty status of the respondents. Where poverty is the dependent variable, and Gender, Age, Household Size, Education Level, Primary occupation, Monthly income earned from Non-farm Activities, Crops which are farming by farmers, Total Earning from Farm Activities (yearly), Total Earning from Cattle, Goats, Sheep (yearly).

Table 1: Socio-Economics Characteristics of the respondents

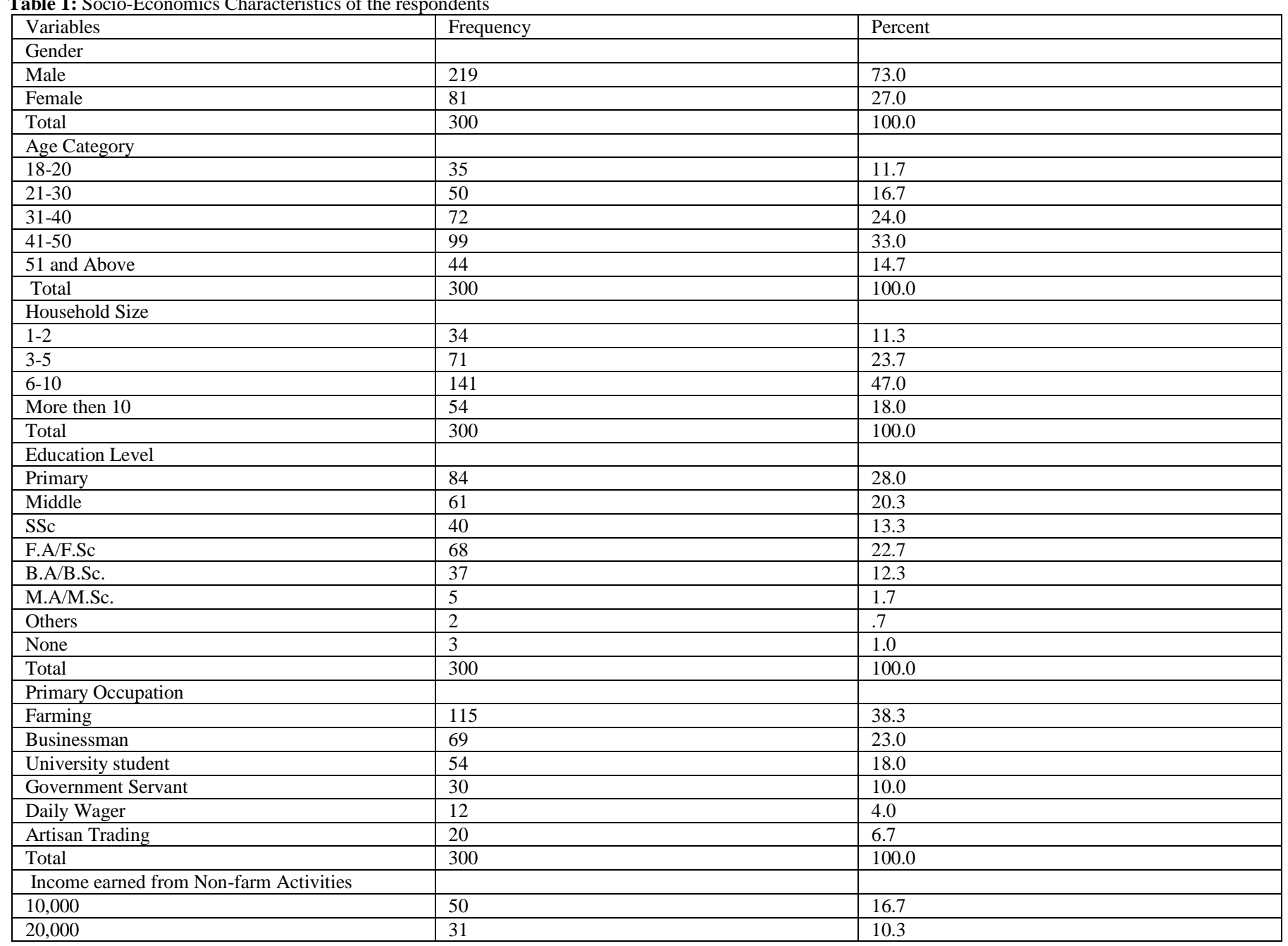


Citation: Waqar Ahmad and Tingwu Yan, 2018. Effect of Non-farm income on Poverty Status Among rural farmers in Pakistan (A Case Study of Tehsail Bahrain District Swat). Advances in Environmental Biology., 12(1): 6-10

\begin{tabular}{|c|c|c|}
\hline 30,000 & 124 & 41.3 \\
\hline 40,000 & 76 & 25.3 \\
\hline 50,000 & 12 & 4.0 \\
\hline 60,000 and Above & 7 & 2.3 \\
\hline Total & 300 & 100.0 \\
\hline \multicolumn{3}{|c|}{ Crops which are farming by farmers } \\
\hline Sunflower & 57 & 19 \\
\hline Potatoes & 103 & 34.3 \\
\hline Maize & 76 & 25.3 \\
\hline Vegetables & 53 & 17.7 \\
\hline Others & 11 & 3.7 \\
\hline Total & 300 & 100.0 \\
\hline \multicolumn{3}{|c|}{ Total Earning From Farm Activities } \\
\hline 10,000 or below & 122 & 44.7 \\
\hline 20,000 & 100 & 33.3 \\
\hline 30,000 & 53 & 17.7 \\
\hline 40,000 & 23 & 7.7 \\
\hline 50,000 & 2 & 0.7 \\
\hline Total & 300 & 100.0 \\
\hline \multicolumn{3}{|c|}{ Total Earning from Cattle, Goats, Sheep (yearly). } \\
\hline 15,000 or below & 219 & 73.0 \\
\hline 30,000 & 69 & 23.0 \\
\hline 45,000 & 8 & 2.7 \\
\hline 75000 & 2 & 0.7 \\
\hline Above & 2 & 0.7 \\
\hline Total & 300 & 100 \\
\hline
\end{tabular}

Table 2: Poverty Status of the respondents

Table 2: Poverty Status of the respondents
\begin{tabular}{|lll|}
\hline Poverty Status & Frequency & Percentage \\
\hline Core poor & 130 & 43.3 \\
\hline Moderately Poor & 90 & 30.0 \\
\hline Non-Poor & 80 & 26.7 \\
\hline Total & 300 & 100.0 \\
\hline
\end{tabular}

Table 3: Tobit regression result for determinants of poverty status

\begin{tabular}{|l|l|l|l|}
\hline Variables & Coefficient & Std. Error & z-Statistic \\
\hline Gender & 0.101704 & 0.105414 & 0.964805 \\
\hline Age & 0.071572 & 0.044723 & 1.600342 \\
\hline Household Size. & -0.022382 & 0.064675 & -0.346060 \\
\hline Education Level. & -0.024437 & 0.029796 & -0.820120 \\
\hline Primary Occupation. & 0.031252 & 0.1095 \\
\hline Income earned from Non-farm activity. & 0.250022 & 0.7293 & 0.030791 \\
\hline Crops which are farming by farmers & -0.031768 & 0.038998 & 1.014985 \\
\hline Income earned from Farm activities & -0.054249 & 0.044207 & 6.411137 \\
\hline Total Earning from Cattle, Goats, Sheep (yearly. & 0.048475 & -0.718627 \\
\hline C & 0.084652 & 0.066001 & -1.119110 \\
\hline
\end{tabular}

If $\mathrm{P}<0.05$ it will be significant, and if $\mathrm{P}>0.05$ it will be insignificant.

\section{RESULT AND DISCUSSION}

Socio economic Features:

The socio-economic characteristics of the respondents are shown in the table (I\&2).Most of the respondents were male about $73.0 \%$ and $27.0 \%$ were female this was due to the ethical consideration because in the study area it is not deemed appropriate for female to be interviewed by a male and there were a shortage of female enumerators. Most of the farmers age is 41-50 (33.0\%).Household Size of the farmers 6-10(47.0\%), Majority of the farmers education level is primary which is (28.0\%).Primary occupation of the respondents are Farming which is (38.3), Most of the farmers monthly income earned from non-farm activities is Rs: $30,000(41.3 \%)$ Pakistani Rupees. Factors which affect the performance of non-farm activity of farmers household engaged is low level of education and skills. Most of the farmers using potato crops in his field because potato of this area is very famous in all over Pakistan. The main reason of household to engage in nonfarm activity is, low income from agricultural activities. Most of the farmers earning from farm activities is very low which is 10,000 or below. Majority of the farmers have a Problems in practicing crop farming because there is an inadequate funds for purchasing inputs (herbicides/pesticides).Total earning from cattle, Goat, and sheep as also not so high. Categorization by Poverty Status

The relative poverty measure was used to categorize the respondent into core poor, moderately poor and non-poor as shown in figure (A). This categorization was based on a measure of per capita expenditure of households on food and non-food items. Households spending Rs 6,000 or less per monthly Pakistani Rupees were categorized as core poor, while those spending between 6,001 and 10,000 were categorized as moderately poor and households spending above 10,000 were categorized as non-poor as shown in the following graph. From the graph it is clear, that in the research area many people are core poor and they have no basic facilities. 


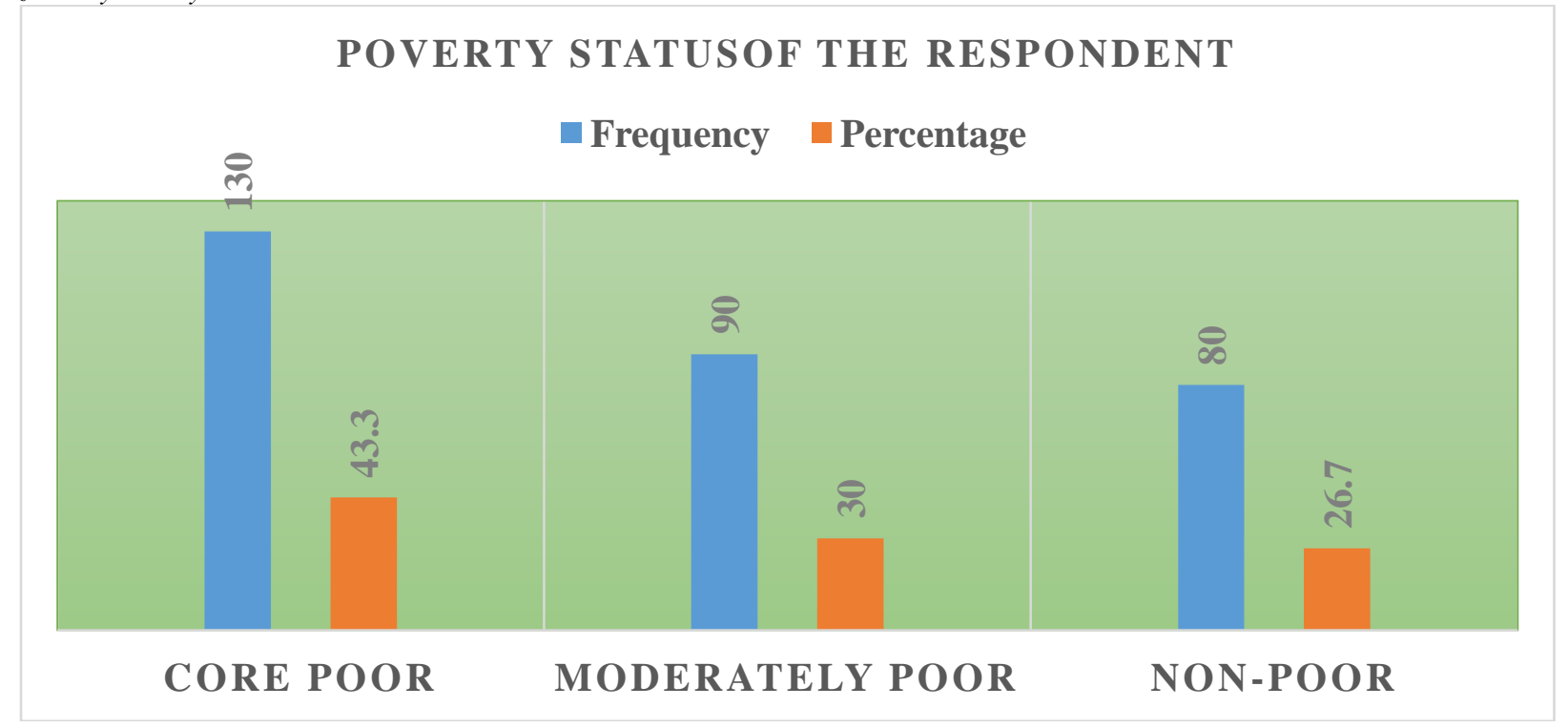

Fig. (A)

Determinants of poverty Status:

Result of the determinants of poverty status of Tehsail Bahrain district swat will be discuss in this section. The author selected these variables which are mention in table (3) because these variables play a very important role in reduction of poverty from rural farmersFrom the table (3) it is clear that the P-value of non-farm income is (0.000) which is less than 0.05 and it is highly significant, which means that is Non-farm income of the respondent increases the poverty status of the farmers will be reducing. Thevalue of $\mathrm{P}$ of other variableslike Household size, education level, and farm income are greater than 0.05 , so they are insignificant, and the coefficient of these variables are negative, which means that is household size and education level and farm income of the rural farmers decreases poverty will be grow up. The intercept value is 0.847 which shows the autonomous poverty categories for farmers in the field of this research. The coefficient of age and Primary Occupation,total earning from cattle, Goats, Sheep (yearly), are positive, which means that when they are increasing the poverty will be worsen.

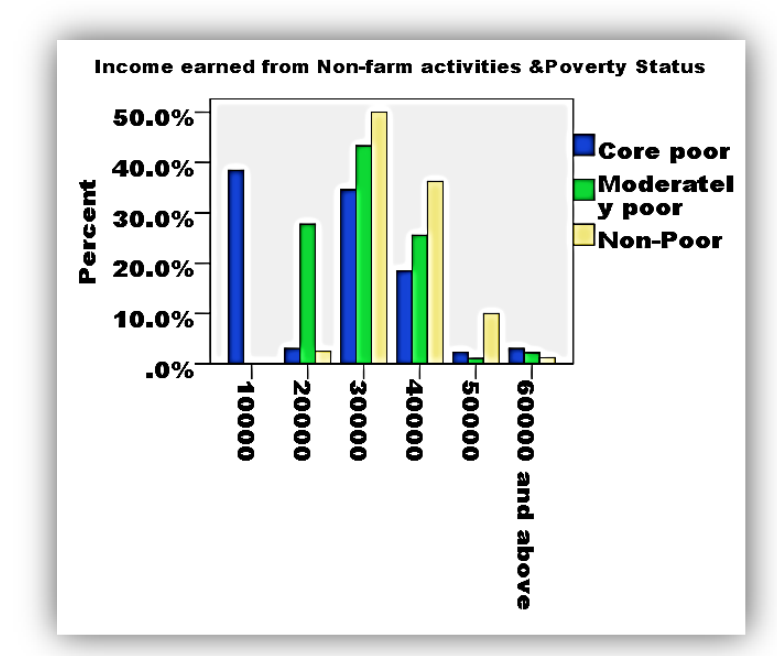

Fig. (B)

From the Figure (B) it is clear that is non-farm income of farmer's increasing the poverty is reducing.

\section{Conclusions:}

This study evaluated the effects of non-farm income on poverty status among rural framers in Tehsail Bahrain District Swat Pakistan. TheTobit-regression revealed that poverty and total monthly income earned from non-farm activities is a significant relationship as the value of significance is less than 0.05 as shown in the Table(3).So it is recommended that farmers of rural areas of Tehsail Bahrain District swat should be facilitated in their engagement in non-farm activities. In addition, the study established that rural non-farm income earned contributed to reducing poverty of rural farmers household. The income earned from these was used by participating farmers in a variety of ways, in farm and non-farm activities. These finding confirm the study's second hypothesis that non-farm income contribute to reducing poverty.

Policy implication:

$\checkmark$ Education and training are indispensable for building the trust and technical and commercial skills of individuals in order to improve the performance of non-farm income.

$\checkmark \quad$ At the same time, agricultural activities should also be promoted. Agricultural production and income are the basis of domestic food supply and often provide the source of capital for the startup and operation of non-farm activities. 

in rural areas.

$\checkmark \quad$ Increase the supply of basic needs, and also increase the personal income.

$\checkmark$ Govt should start other program like BISP, to reduce poverty from rural household.

\section{ACKNOWLEDGMENTS}

The financial support for the current study was supported by National Natural Science Foundation of China (41371520), and Major Research Project of Philosophy and social Science of Ministry of Education of China (15JD014), and the Fundamental Research Funds for the Central Universities (2662015PY214).

\section{REFERENCES}

[1] ADB, \& PRM,2002.Poverty in Pakistan: Issues, causes and institutional responses (July),1-79.

[2] Ahmad, W.,(2017).The Role of Benazir Income Support programme in Poverty Reduction : A Case Study of the Selected Villages in District Swat, 3(4): 5869.

[3] Chaudhry, I.S.,2009. Poverty Alleviation in Southern Punjab(Pakistan): An Empirical Evidence from the Project Area of Asian Development Bank. EuroJournals, 23(23): 23-32.

[4] Centre, D.,2017.Poverty and Vulnerability Estimates: Pakistan, 2016, (99).

[5] Jamal, H.,2006.Does inequality matter for poverty reduction? Evidence from Pakistan's spoverty trends. Pakistan Development Review,45(3):439-459.

[6] Ali A, Erenstein O, Rahut DB. Impact of gender participation in non-farming activities on household income and poverty levels in Pakistan. Work. 2015 Jan $1 ; 52(2): 345-51$.

[7] FAO., 1998. The state of food and agriculture 1998, (Rome, FAO).

[8] Che-Mat SH, Jalil AZ. The impact of non-farm income on the incidence of poverty among farmers in Kedah, Malaysia. International Journal of Trade, Economics and Finance. 2011 Aug 1;2(4):326.

[9] Lanjouw JO, Lanjouw P. The rural non-farm sector: issues and evidence from developing countries. Agricultural economics. 2001 Oct 1;26(1):1-23.

[10] Haggblade S, Hazell P, Reardon T. The rural non-farm economy: Prospects for growth and poverty reduction. World development. 2010 Oct 1;38(10):142941.

[11] Lanjouw P, Murgai R, Stern N. Nonfarm diversification, poverty, economic mobility, and income inequality: a case study in village India. Agricultural Economics. 2013 Jul 1;44(4-5):461-73..

[12] Management, F.,2016. Effects of Farm and Non-Farm Income on Income-Inequality among Rural Households in Osun - State , Nigeria, 25(2008), 1-10.

[13] Lei, S. U. N., 2017. Non-Farm Income and Income Inequality: An Empirical Study Based on the Income Distribution of Farmers in Liaoning and Jilin Provinces, 14(1): 33-39. https://doi.org/10.3968/9321.

[14] Farooq, S.,2014.The Rural Non-farm Economy, Livelihood Strategies and Household Welfare in Rural Pakistan, 0-35.

[15] KPBOS., 2016. KPK bureau of statistics Retrieved from http:// kpbos.gov.pk. 